To be published in the Harvard Journal of Law and Public Policy. Copyright 2003 by Jack M. Balkin. All Rights Reserved.

\title{
THE PROLIFERATION OF LEGAL TRUTH
}

\author{
JACK M. BALKIN
}

I am delighted that the Federalist Society asked me to participate in its Symposium on Law and Truth. I suspect, however, given my previous jurisprudential writings, that I was invited in order to play the role of Pontius Pilate. But I refuse that responsibility. I wash my hands of it. For I am a great believer in legal truth. Indeed, the theme of this essay is that we are awash in legal truth; indeed, we are drowning in it. In the world in which we live, legal truth is proliferating at an astounding pace, and this truth has important effects on our lives for good and for ill. The proliferation of legal truth and the effects of power produced by that proliferation are the subjects of this essay.

In his remarks for this symposium, Michael Moore suggested that I am a conventionalist when it comes to legal truth. With respect to law, at least, he is right, although not necessarily with respect to other matters. Law is an interpenetrating set of social conventions, and therefore statements of law can be true by virtue of those conventions. To be sure, these conventions may not be fully specified or fully determinate, and their content can change over time. In this essay, however, I focus on the converse point, that when legal conventions are sufficiently specified and sufficiently determinate, they can and do decide what is true or false from the standpoint of law.

There are lots of true legal propositions; indeed, so many that

* Knight Professor of Constitutional Law and the First Amendment, Yale Law School. My thanks to Bruce Ackerman, Sanford Levinson and Reva Siegel for their comments and suggestions.

1. A previous version of this essay was given as a speech at the Federalist Society Conference on Law and Truth, March 1-2, 2002, Yale Law School.

2. Michael Moore, Law and Truth: Pre-Modernism, Modernism and Post-Modernism, Address at Federalist Society Conference on Law and Truth at Yale Law School (Mar. 12, 2002). See also Michael Moore, ARTICLE TITLE, 26 HARV. J.L. \& PUB. POL'Y (2002).

3. See J. M. Balkin, Cultural Software: A Theory of IdeOlogy 142-50 (1998). 
I can't even begin to list them. They are true by legal convention, in virtue of the social practices that constitute law. As Susan Haack puts it, they are true as legal claims. Or as common law lawyers would put it, they are true in the eyes of the law. In fact, one of the most interesting features of law as a system of social conventions is its ability to make things true or, to put it another way, to create legal categories that permit characterizations of situations and practices that are true or false. My point, however, is not simply that propositions of law are true in virtue of legal conventions. It is rather that law creates truth-- it makes things true as a matter of law. It makes things true in the eyes of the law. And when law makes things true in its own eyes, this has important consequences in the world.

Consider, for example, the common law distinction between trespassers, licensees, and invitees. Landowners have different tort duties toward people who trespass on their property, enter their property for business reasons, or visit as invited social guests. Simply by making these distinctions, the common law makes it possible for it to be true or not true that a person is a trespasser, licensee or invitee.

Sexual harassment law makes it illegal to engage in sexual harassment. At the same time, it defines a practice as understood by law called sexual harassment. It makes it possible for someone to be a sexual harasser or not be a sexual harasser in the eyes of the law. It creates legal rights against sexual harassment and makes it possible to protect and violate these legal rights. Similarly, when law creates intellectual property rights in computer code, it makes it possible to violate those rights, to be or not to be a copyright infringer.

When law allows companies to create $401(\mathrm{k})$ plans, or when it provides general statutes of incorporation, it defines

4. Susan Haack, Law and Truth: Pre-Modernism, Modernism and Post-Modernism, Address at Federalist Society Conference on Law and Truth at Yale Law School (Mar. 12, 2002). See also Susan Haack, ARTICLE TITLE, 26 HARV. J.L. \& PUB. POL'Y (2002).

5. The metaphor that compares legal truth to legal vision, "law's eyes," is a familiar trope in legal scholarship. See generally, NORMA BASCH, IN THE EYES OF THE LAW: WOMEN, MARRIAGE, AND PROPERTY IN NiNETEENTH-CENTURY NEW YoRK (1982); Reva B. Siegel, In the Eyes of the Law: Reflections on the Authority of Legal Discourse, in LAW'S STORIES: NARRATIVE AND RHETORIC IN THE LAW 225-231 (Peter Brooks and Paul Gewirtz eds., 1996) (emphasizing how law gains authority from its construction of discourse). 
institutions and practices that people can bring into being. It makes possible true and false statements about these institutions and practices, and about rights and responsibilities with respect to them.

Thus, there several different ways that law can make things true. Sometimes law makes things true just by creating categories and distinctions that define certain situations or conduct vis-à-vis other kinds of situations or conduct, or that make things equivalent or different from the standpoint of legal doctrine. Sometimes law makes things true by creating causes of action or rights, as in sexual harassment law or intellectual property law. And sometimes law makes things true by creating institutions or devices, like a corporation or a Roth IRA or a 401(k) plan. When the law does any of these things, it simultaneously creates the possibility of things being true or false in the eyes of the law.

So in this sense, law is continuously proliferating truth into the world. It is making things real. It is making things true and false. These things are not true and false from the standpoint of mathematics or natural science. Rather, they are true and false from the standpoint of law. But the truth that law produces is nothing to sneeze at. Because law is a form of power that is backed up by and helps constitute the authority of the state, what the law says is real, and what the law says is true or false has important consequences in the world. Put another way, law's capacity to create truth and make things real is the flip side of its power. Law has power because it can make things true or false in ways that matter to us; conversely, law can make things true or false in ways that matter to us because it has power over us.

Why is this proliferation of legal truth and legal reality important? It is important, I think, for three reasons. First, the proliferation of legal truth shapes, directs, and constrains how people live their lives. It produces incentives and disincentives for people's conduct. Second, the proliferation of legal truth shapes people's beliefs and understandings. Law has power over people's imaginations and how they think about what is happening in the world. Third, the proliferation of legal truth is important because law's truth is not the only truth, and law's vision of reality is not the only reality. Law's power to enforce its vision of the world can clash with other practices of 
knowledge, and with other forms of truth.

Let me address each of these points in turn.

Law continuously creates a form of knowledge-legal knowledge. As soon as law creates a category or an institutional structure, it is possible for things to become true or real in the eyes of the law whether or not they are judged true or real from another perspective-- for example the standpoint of medical science, religious belief, or political philosophy. So as soon as we create a doctrine that says that money is speech, then money is speech in the eyes of the law. It doesn't matter whether we know that money is not speech. The law says it is speech and therefore it is speech in the eyes of the law.

Similarly, if the law says that a fetus is not a person, then it does not matter that religious faith tells us that the law is wrong, and that the law is effectively legitimizing murder. A fetus is simply not a person in the eyes of the law. This has obvious political ramifications, for it places the power of the state behind a certain conception of how the world is and what is true and false within it, whatever one's views to the contrary might be and no matter how vociferously one expresses them.

My second point follows from the first. I have just asserted that things can be true from the standpoint of law even if people don't believe them to be true in other respects. But the proliferation of legal truth is also important because law does shape what people believe and what they understand. Law has power over people's imaginations and how they think about what is happening in social life. Law in this sense is more than a set of sanctions. It is a form of cultural software that shapes the way we think about and apprehend the world.

Law adds things to reality. And it colonizes the human mind. That is how it proliferates its power over the world. A very familiar conception of law is Holmes' model of law as a sanction or a price. A rational actor faces constraints created by

6. See Buckley v. Valeo, 424 U.S. 1, 19 (1976) (per curiam) ("virtually every means of communicating ideas in today's mass society requires the expenditure of money"); see also J. Skelly Wright, Politics and the Constitution: Is Money Speech?, 85 YALE L.J. 1001 (1976).

7. See Roe v. Wade 410 U.S. 113, 158 (1973) ("the word "person," as used in the Fourteenth Amendment, does not include the unborn.").

8. BALKIN, supra note 3, at 5-6.

9. See Oliver Wendell Holmes, Jr., The Path of the Law, 10 HARV. L. REV. 457, 458-59 (1897). 
law and has to decide how to behave given the likely legal consequences of his or her actions. ${ }^{10}$ From this standpoint alone the law is surely proliferating things into the world: it is proliferating prices and probabilities of certain sanctions.

But I want to take Holmes' point a step further. Law also proliferates ways of characterizing a situation or understanding the situation as being one sort of thing rather than another. Sexual harassment law is a good example. Before the development of sexual harassment law, there may or may not have been a generally recognized social practice called sexual harassment. People were struggling to give it a name and to condemn it. ${ }^{11}$ But there was no such thing legally. There were only legal actions for seduction (if they had not been abolished by statute), assault, or intentional infliction of emotional distress. After the creation of sexual harassment law, it became possible to identify a certain set of practices as sexual harassment from the standpoint of law. Indeed, it also became possible to be a sexual harasser. It became possible to understand one's own actions as being or not being sexual harassment. It became possible for employers to engage in certain types of behavior, and to instruct employees to engage in certain types of behavior, so as not to be guilty of sexual harassment.

In this way law creates tools for understanding one's self, others, and the social world in which one lives. Those legal understandings, in turn, can merge with and shape popular understandings of sexual harassment is. These popular understandings are not necessarily the same as the technical

10. See id at 458-59. Holmes's view of the law as a sanction or price anticipates a basic insight of law and economics scholarship. Although in recent years lawyer economists have also emphasized the ways that law can express social norms, they have hardly abandoned the notion that law (or social norms for that matter) set a price on conduct. My focus, by contrast, is how law and social norms are forms of cultural software, which shape how one apprehends the world and understands what is socially the case.

11. See Reva B. Siegel, "On the Basis of Sex" : A Short History of Sexual Harassment, in Directions in Sexual Harassment Law (Catharine A. Mackinnon \& Reva B. Siegel eds. forthcoming 2004) (tracing history of sexual harassment doctrine); Susan Estrich, Sex at Work, 43 STAN. L. REV. 813, 816-26 (1991) (tracing the development of sexual harassment as a cognizable claim of sex discrimination under Title VII); see generally LIN FARLEY, SHAKEDOWN: THE SEXUAL HARASSMENT OF WOMEN ON THE JOB (1978) (discussing sexual harassment as a political and social problem); CATHERINE A. MACKINNON, SEXUAL HARASSMENT OF WORKING WOMEN (1979) (advocating recognition of sexual harassment as sex discrimination under Title VII). 
legal definition, but are shaped and nourished by the legal recognition of the practice; conversely, the legal practice can be shaped and nourished by popular understandings of the legal concept.

Indeed, the very expression-the "legal recognition" of a cause of action - suggests the important connection between what law sees as socially real and what it makes socially real though its authority as law. When law "recognizes" a cause of action for sexual harassment, for example, it sees that such a thing exists as a legal wrong. At the moment the wrong becomes cognizable to the law, it becomes real to the law, whether or not it had been real to generations of individuals before that point. In like fashion, when courts hold that software code is "speech" under the First Amendment, they recognize or see the code as speech, placing it in the same category or conceptual box as other examples of speech, including giving a commencement address, performing a sexual act in a motion picture, distributing a pamphlet, waving (or burning) a flag, or writing a check to a political action committee. In that moment, all of these activities become speech in the eyes of the law, differentiated from other things that are not speech in the eyes of the law.

What law is doing, in short, is more than simply giving people sanctions or prices for their conduct. What law is doing is giving people tools to think with. It is giving people a way of understanding and apprehending what is the case. Law enables people to understand what is socially real in terms of legal categories, in short, in terms of what is real to the law.

This way of seeing the world - through the eyes of the lawhas important ideological effects. Often people contrast truth to ideology. If something is ideological, it can't be true, and vice versa. That is not my view of ideology. Ideology is cultural software. It is a set of tools for apprehending and understanding who you are and what is happening to you, what the world around you is like, and so on. And those tools of understanding have power over you because they shape your

12. See, e.g., Universal City Studios, Inc. v. Corley, 273 F.3d 429, $447-49$ (2d Cir. 2001); Junger v. Daley, 209 F.3d 481, 484-85 (6th Cir. 2000); Bernstein v. United States Dep't of Justice, 176 F.3d 1132, 1139-41, reh'g granted en banc and opinion withdrawn, 192 F.3d 1308-09 (9th Cir. 1999).

13. See BALKIN, supra note 3, at 5-6. 
understanding. ${ }^{14}$ So it is not self-contradictory to say that imagining the world through the eyes of the law, or seeing things in terms of what is true from the standpoint of law, could have ideological effects on human beings. It tends to push their imaginations in one direction rather than in another. It opens up some possibilities for thinking while foreclosing others. This power over the imagination is the power of ideology. ${ }^{15}$ Shaping people's imaginations and understandings of who they are and what they are doing is one of the most important forms of power that law possesses.

One might think that the problem with law's power is that it compromises one's ability to understand what is true, because what is true from the standpoint of law is not really true. Therefore, when one sees things as law sees them, one is deluded or one's perception is distorted in some way. But it is important not to try to reduce all of law's ideological effects to distortion or misrepresentation. The way law imagines sex discrimination may not be the most just or reasonable way to think about the problem. But that does not mean that the only work that law performs is to distort or falsify the social world. Rather, law adds something to the social world: legally created categories and institutions that have consequences for how people think and behave. What law brings to the world is the way that world looks to law.

The statutory scheme that allows employers to create $401(\mathrm{k})$ plans adds something to the world; it does not simply distort or mischaracterize it. The creation of a 401(k) plan obviously shapes economic incentives and some economists might even say it distorts incentives to save. But its effects do not stem merely from a false representation of the world. Rather, the statutory scheme is helping to make things in the world. Law creates new concepts, distinctions, entities and institutions that, in turn, create the possibility of new truths and new falsehoods. Law makes it possible for certain propositions to be true or false that could not have been true or false before, such as, "Mary contributed to her 401(k) account" or "John made an unwelcome advance to Mary and is a sexual harasser."

14. See id. at 273-76.

15. Id. at 5-6, 126-29, 280, 282.

16. See id. at 214-15 (discussing ideological effects of narrative construction). 
One can certainly complain that sex discrimination law misdescribes the problems of equality in the United States, but it does more than simply misrepresent the problem of equality. Sex discrimination law shapes the terms under which people understand there to be a problem of equality or not. It creates new categories of defining and describing behavior. It creates new opportunities to treat people equally and unequally. It supplements and equips the social world as well as distorting or misrepresenting it. Law exercises its power over people by creating reality and proliferating truth, not simply by misrepresenting reality and distorting truth.

What law does, and can do, is proliferate ideas, concepts, institutions and forms of social imagination, which can attach themselves to, reorganize, and even displace existing forms of social understanding, social practice, and social reality. Law has the opportunity to do this because of its status as law, because it is intertwined with, supports and is supported by the power and authority of the state. Because law is law, it matters what things look like to law and how law characterizes them.

This brings me to the third reason why the proliferation of legal truth is important. It should be obvious from the expressions "truth in the eyes of the law" or "true from a legal perspective" that the kind of truth and reality that law creates is not the only sort of truth, or knowledge, or reality that people care about or think important. There are many other forms of knowledge acquisition in the world, and many other conventions through which and purposes for which people try to determine what is true or false, try to gather and assess knowledge. Examples include medicine, psychiatry, psychology, and natural science, as well as social science, history, and religion.

These other forms of life also produce knowledge, and things that are true and false from their standpoint. Legal knowledge can come into conflict with these other forms of knowledge. One might ask: how is it possible that things can both be true and yet come into conflict? The answer is that things that are true from the standpoint of one set of social practices or social conventions are not necessarily true from the standpoint of another. The practices may be looking at very different things and they may be asking very different sorts of questions. The reason why law can come into conflict with other forms of truth 
and other forms of knowledge is that truth and knowledge are shaped by institutional purposes. Legal knowledge exists to regulate and declare what is legal or not legal. Medical knowledge exists for other purposes. Therefore, it is possible for something to be judged true from the standpoint of law and not be judged true from the standpoint of medical knowledge. That is because legal judgments of truth and falsity are designed to mesh with legal institutions and legal categories of judgment. A legal test such as "beyond a reasonable doubt" or "supported by substantial evidence in the record" need not correspond to the standards or judgments of any other profession. If the legal test is met, however, then the legal result is true from the standpoint of law.

A similar conflict may occur between legal and historical judgments about truth. Historians have a certain set of professional conventions about good and bad historical writing and good and bad argument. But these concerns may be at cross purposes with the interests of lawyers who are interested in invoking history and historical studies for the purposes of legal argument. Historians may want to complexify; lawyers may want to simplify. Historians may want to find truth in multiple trends and perspectives; lawyers may want a relatively straightforward answer that can be invoked to solve a legal question. Historians may resist anachronism and imaginative abstraction; lawyers may embrace both of these things.

Furthermore, because the legal system tends to look at things from the standpoint of law and its purposes and interests, the world may simply appear very different to law than to another field of knowledge creation, such as medicine. My favorite example is a patient who walks into an emergency room. From the standpoint of medical knowledge the patient is a set of clinical problems to be tested, identified, diagnosed and cured. From the standpoint of legal knowledge the patient is a potential tort suit. The practices of medical knowledge are devoted to asking what sort of disease or condition the patient has, then recognizing, classifying, treating and curing it. The practices of legal knowledge are devoted to asking how the rights of the patient, the doctor, the hospital, and the insurance company are affected by what these actors do or fail to do. Both practices may produce true statements, but these true statements may have no obvious connection to each other and they may even be 
in conflict. It is important to understand that the conflict between the truths of law and medicine, when it occurs, does not violate the laws of logic. It is not a logical contradiction but a clash of institutions and purposes.

Even though these forms of knowledge have distinct goals and purposes, they may nevertheless interact in important ways. The way that medicine is practiced and the types of medical knowledge that are gathered and ascertained may be shaped by the possibility that the patient is a potential tort plaintiff, that the patient has insurance or does not have insurance, and so on. In this way law does more than simply describe the world. It not only colonizes the mind; it can also colonize other forms of knowledge. In this way law's truth, or what is true in the eyes of the law, can reshape and redirect (some would even say distort) the gathering and collection of medical knowledge, and the methods and devices through which medical truth is ascertained, promulgated, and articulated.

In this essay I have taken a strongly positivist line. I have argued that legal conventions create, inform, and support judgments of legal truth. But I have not viewed this as grounds for praise. A person can be found guilty even if they did not commit the act they were charged with; money can be political speech according to judicial doctrine even if it displaces democracy and drowns deliberation; people can be viewed as equal in the eyes of the law even if their circumstances are so divergent that the claim of law's evenhandedness makes a mockery of equality and a travesty of neutrality. Legal claims can be true in the eyes of the law even if they are not true in the eyes of the morally sensitive layperson or lawyer-even if they distort and deform social relations, even if they debauch moral thinking and mutilate human life.

The point of my approach is not to deny the truths that law produces but to face them squarely, acknowledge them as real things with real consequences for human life. I take a strongly positivist or conventionalist line in this essay because it is important to understand the proliferation of legal truth, and the proliferation of its power, not as mere defects or imperfections

17. To be sure, this colonization is a two way street, for medical knowledge can (and does) affect the developing forms of legal argument and legal practice. A contemporary example is how the legal concepts of innocence and finality of legal proceedings are affected by the discourse of genetics. 
extraneous to law but as central features of what law is and what law does. H.L.A. Hart once pointed out that whatever positivism's faults as a theory of law, it has the distinct virtue of permitting a healthy degree of skepticism about the justice and morality of existing legal systems. It does not sugarcoat law or bestow it with greater moral legitimacy than it deserves. Conventionalism-for legal positivism is but one form of conventionalism-gives us a perspective against which we can criticize law, acknowledge its defects, identify its forces and name its harms.

That is not the only way one could think about law. One might insist that an aspiration for justice and goodness is to be found within the concept of law itself, and that law must continually draw on the best parts of itself to work itself pure. But to speak in this way tends to downplay the force of legal truth, the imbrication of law's power in social life and in the human imagination. Law's construction of a social world and its development of the social imagination can do enormous good. But it always also has other effects. It always also serves other ends, including the empowerment of legal institutions and legal forms of thinking.

Indeed, it is precisely law's normative force-the felt sense that law aspires to articulate and realize important human values-that gives it such power to structure the moral imagination, so that moral and political questions become transformed into questions of law and legal interpretation. Law and legal concepts can and do become part of utopian imagination about the direction and production of a better world. Yet if people articulate their political and moral ideals through legal concepts and in legal terms, they are not escaping the proliferation of legal truth. They are contributing to its spread.

Thus, my point is not simply the familiar one associated with positivism - that the law need not be just or moral to have the status of law. Rather, my point is to focus on the ways in which legal concepts, legal thinking, and legal imagination colonize moral and ethical imagination. To do this, we must pay careful attention to the many ways in which law and morality are not

18. See H.L.A. Hart, Positivism and the Separation of Law and Morals, 71 HARV. L. REV. 593, 597-99 (1958). 
separated, the many ways in which the moral imagination becomes ensnared by and held in servitude to the legal. Then the truth of law does not necessarily set us free.

In this essay I have also emphasized how legal conventions can fix what is true or false from the eyes of the law. But it should be obvious that legal conventions are not always fixed, uncontroversial, complete, or adequately specified in many situations. Even so, the force of my argument is not vitiated when we take legal indeterminacy into account. For law to shape our cultural software and exercise its power over our social imaginations, it is not necessary that everyone agree which propositions of law are true and which are false, or hold that legal conventions fully and uncontroversially specify the application of legal norms in every situation. It is only necessary that legal concepts and institutions shape the ways that people apprehend, understand, reason, and argue about their social world, and hence shape the contours and delineate the boundaries of their disagreements. Even if people argue about whether a display of pornography in the workplace can constitute a hostile environment, they are still arguing in terms of the legal concept of hostile environments. Even if people are uncertain whether a particular restructuring of a business transaction makes a certain tax deduction available to a corporation, their uncertainty is offered against the background of legally created institutions and concepts. And even if one is a constitutional protestant and denies that the United States Supreme Court has a monopoly on the meaning of the Constitution, one is still imagining political ideals in terms of the Constitution's language, conceptions and institutions.

Thus, the proliferation of legal truth exists easily alongside legal disagreement and legal dissensus. Legal truth persists through historical changes in legal conventions and legal structures. Legal indeterminacy does not attenuate law's conquest of the imagination. If anything, it may enhance it, by encouraging discussion about the meaning of laws and about the right answers to legal questions. Legal indeterminacy can actually proliferate law's power by spurring people to think, talk, contest, and argue using legal frameworks, legal concepts,

19. See SANFord Levinson, Constitutional Faith 27-30, 37-50 (1988). A protestant approach to the Constitution looks to "the legitimacy of individualized (or at least nonhierarchical communal) interpretation." Id. at 29. 
and legal terms.

Law's power grows organically and relentlessly out of law's colonization of social imagination. Legal power is ramified and spread through its ability to make things real and to make things true. Law and legal conceptions become interwoven in the fabric of everyday life, and in the cultural software that members of a community employ to understand their practical situation. In this way law becomes an inseparable element of the techniques of socialization, with all of their internalized force. Law is at its most powerful when it is most cultural, when it is most invisible, when it is most seamlessly integrated into practical and moral reasoning. Law is most powerful when we see the world through its eyes, when its understanding becomes part of our understanding, and when its truth becomes part of our truth. 